\title{
THE ROLE OF LOCAL FOOD PRODUCTION TO REDUCE FOOD LOSSES AND IMPROVE REGIONAL ECONOMY
}

\author{
João Roberto Maiellaro \\ PPGEP/UNIP and Fatec Zona Leste, Brazil \\ E-mail: joao.maiellaro@fatec.sp.gov.br \\ João Gilberto Mendes dos Reis \\ PPGEP/UNIP and Fatec Zona Leste, Brazil \\ E-mail: betomendesreis@msn.com \\ Fernando Juabre Muçouçah \\ Fatec Ferraz de Vasconcelos, Brazil \\ E-mail: f292dir@cps.sp.gov.br \\ Oduvaldo Vendrametto \\ PPGEP/UNIP, Brazil \\ E-mail:oduvaldov@uol.com.br \\ Robson dos Santos \\ Fatec Zona Leste, Brazil \\ E-mail: robson@fatec.sp.gov.br
}

Submission: $22 / 08 / 2018$

Revision: 13/09/2018 Accept: 24/09/2018

\section{ABSTRACT}

Brazil is one of the most important agricultural producers worldwide. However, the nation faces logistics and distribution matters due to the size of the country. Therefore, local food producers are fundamental to Food Supply Chains performance. They are near to the consumers and reduce the logistics impacts. To understand the role of local food producers, this study analyzes the Local Food Production in Mogi das Cruzes and the support of the local government. The city is the hub of Sao Paulo's metropolitan green belt. We collected data directly from the Municipal Secretariat of Agriculture. The results suggest that the local government performs technical and legal actions and there is a concerning in supporting the local food producers, keep on this economic activity in a good level

efficiency. 
INDEPENDENT JOURNAL OF MANAGEMENT \& PRODUCTION (IJM\&P)

http://www.ijmp.jor.br

v. 10, n. 2, March - April 2019

ISSN: 2236-269X

DOI: 10.14807/ijmp.v10i2.861

Keywords: Local Food Production; Green Belt; Mogi das Cruzes city

\section{INTRODUCTION}

Brazil is one of the most important countries in agribusiness of the world. An estimation of 2017 for the Brazilian harvest of cereals, vegetables and oleaginous totaled 221,400,000 tons, 20.3\% higher than 2016 when the production reached 184 million tons. The estimated harvested area is 59,900,000 hectares in 2017, that represents an increase of $4.9 \%$ compared to 2016 , with $57,100,000$ hectares.

Rice, corn and soybeans are examples of very important products of this group, which, together, accounted for $93.5 \%$ of total estimated production and $87.4 \%$ of the harvested area. Compared to the previous year, there is an increase of $1.9 \%$ in soybeans, $10.3 \%$ in corn and $1.2 \%$ in rice. About production, there was an increase of $11.8 \%$ for soybeans, $10 \%$ for rice and $38.9 \%$ for corn (IBGE, 2017).

From a supply chain perspective, the globalization in the agribusiness sector has influenced Food Supply Chains (FSC) that are affected by increasing the distance between food production and the consumers. This situation not only has enlarged emissions of greenhouse gases but also has decreased the relationship between local food producers and consumers (BOSONA; GEBRESENBET, 2011).

Another fundamental factor relies on the fact that distance raises the food losses along the supply chains. The Food and Agriculture Organization of United Nations (FAO) estimates that one-third of all food produced globally for human consumption is lost during the stages of production and transport or wasted after the food purchasing, during the stages of cooking, sorting, and consumption (FAO, 2013).

Indeed, packing, storage, inventory management and transportation can be very challenging for FSC. There is often significant time pressure on post-harvest activities as most agricultural products are perishable. Hence, a postponement in transport may cause high losses (BEHZADI, et al., 2018).

Currently, one of the solutions analyzed to reduce these losses in the logistics process is increase the participation of Local Food Producers. There is a global movement in the sense of offers conditions for local producers who attends this 
INDEPENDENT JOURNAL OF MANAGEMENT \& PRODUCTION (IJM\&P)

http://www.ijmp.jor.br

v. 10, n. 2, March - April 2019

ISSN: 2236-269X

DOI: 10.14807/ijmp.v10i2.861

demand. In Brazil is not different and many municipalities are developing assistance programs to these producers that involve investments and buy products.

Mogi das Cruzes, for instance, considered the most important city in the green belt of the metropolitan region of São Paulo, produce and supply several types of food and flowers beside employed a huge workforce. Despite the importance of the city production some questions need to be answered as for how does the local government supports and manage the local food production? how does the local government monitor the activities of local production and how does the local food is sold nearby with the support of the local government?

This paper aims to investigate the local food production in the Mogi das Cruzes city, and to bring a wide range of information about the local government activities to help and support local food producers. This knowledge could be used to find solutions to improve production in distribution in the city and at the same time contribute with benchmarking information for other cities in Brazil and the World

The paper is divided as follows: a literature review, methods, results and discussion and finally, it presents the conclusions and suggestions for future studies.

\section{LOCAL FOOD PRODUCTION}

The literature discusses concepts of Local Food Production (LFP) often. It is difficult to draw conclusions about the local economic impact of local foods systems. Many studies perform narrow geographic and market scope. It is challenging to make comparisons establishing operational, logistics and government support aspects. Micro-scale business concepts have become more common around the world, and there is increasing interest in these among consumers (MIGLIORE et al., 2015). Consumers are in pursuit of different sources of food produced near their home (MIGLIORE et al., 2014; NIE; ZEPEDA, 2011).

Short Food Supply Chains (SFSC) allow understanding how and where food is produced, enabling the development of a trust relationship between consumers and producers. The main methods that could help researchers to achieve certainty are implemented to SFSCs in face-to-face relations with consumers and connecting products to their regional features (AGGESTAM et al., 2017). 
INDEPENDENT JOURNAL OF MANAGEMENT \& PRODUCTION (IJM\&P)

http://www.ijmp.jor.br

v. 10, n. 2, March - April 2019

ISSN: 2236-269X

DOI: 10.14807/ijmp.v10i2.861

SFSCs are more accessible to producers who speak the same language as their consumers and who share similar social, economic and environmental values (JAROSZ, 2011).

The term local food slips effortlessly of the tongue and while an everyday common-sense approach might suggest that local food is produced and consumed within a scarcely well-defined geographical area, there appears to be no generally agreed or widely adopted definition.

One set of definitions is essentially based on geography and looks to define local regarding the distance between producers and customers, though there is not clear agreement of a limiting distance, or in terms of local authority boundaries. Thus, one of the definitions of local recognized by the National Association of Farmers' Markets (NAFM) is in terms of the radius from the market and while the association suggests that 30 miles is ideal, and 50 miles is however acceptable (JONES et al., 2004).

While the term "local" food is usually seen, there are no criteria. When asked to use political borders, customers generally define the term as food grown within a county or neighboring place, or within a certain city or state. Furthermore, political boundaries do not appear to be the best delineation to define local food.

Scaling food production is a world challenge. Encouraging the involvement of mid-sized farms looks to be a classic solution because it can expand the accessibility of local food while providing alternative revenue streams for troubled family farms. Many barriers stand in the way of such a development. The logistical, structural and regulatory barriers to increased scale in local food systems are well known. Limited understanding about the way in which scale developments affect the perception and legitimacy of local food systems can be a relevant matter (MOUNT, 2017).

Many familiar that defend the local food production might suggest that important pieces of added value within local food systems are generated by the reconnection of producer and consumer, the direct exchange through which this occurs, and the shared goals and values that provide the basis for reconnection (Mount, 2017).

The necessary data to measure the economic local impact are highly costly to obtain, and researchers must agree on a standard way of accounting for the costs 
INDEPENDENT JOURNAL OF MANAGEMENT \& PRODUCTION (IJM\&P)

http://www.ijmp.jor.br

v. 10, n. 2, March - April 2019

ISSN: 2236-269X

DOI: 10.14807/ijmp.v10i2.861

involved of produced and purchased local foods or on a standard set of economic modeling assumptions. Many questions surrounding the economic impact of local foods remain unanswered and could be raised by future researches, e.g., if local food systems help the city-rural economy or if the economic benefits of expanding local food systems might be unevenly distributed (USDA ERS, 2017).

According to the 2001 census in Brazil, in 1991, 233,000 people lived in rural areas of Sao Paulo city and in 2,000 that number reached 620,000 inhabitants. It suggests an interesting gap regarding the definitions of what is considered rural and what is considered urban population. This movement has happened mainly in peripheral areas, occupied by informal settlements and irregular land subdivisions which means this urban population is occupying a rural area, that has lost this main characteristic. Urban population is expanding the boundaries, in areas which are still considered rural by policies and laws (BARBIZAN, 2011).

\subsection{The Importance of The Green Belt of São Paulo And Mogi Das Cruzes City}

Until the middle of the 20th century, Brazilians were not aware of the wide variety of vegetables before the arrival of Japanese immigrants, characteristically diet from the sea and plants. These immigrants had a key role in Brazilian agriculture, bringing new species of vegetables and food in general. Many Japanese immigrants live in the Alto Tietê region and they have dedicated their entire lives to agriculture. The arrival of these immigrants was established through an immigration agreement between Japan and Brazil at the beginning of the 20th century (INSTITUTO FLORESTAL, 2013).

Mogi das Cruzes is considered as the main town in the region of Sao Paulo's green belt, and it has the largest center of production of vegetables, fruits and flowers of Brazil, with a relevant share of the national market of mushrooms, persimmon, loquats, vegetables, and flowers. There are a large presence of farmers with Japanese origin (SANTOS; BELLO, 2014).

Among the legacies left by immigrants and their descendants, there are many techniques of agriculture, as the development of new species of vegetables and flowers, including orchids and various foreign dishes (DA SILVA et al., 2015). 
INDEPENDENT JOURNAL OF MANAGEMENT \& PRODUCTION (IJM\&P)

http://www.ijmp.jor.br

v. 10, n. 2, March - April 2019

ISSN: 2236-269X

DOI: 10.14807/ijmp.v10i2.861

Mogi das Cruzes city is the main food supplier of the Metropolitan region of São Paulo. São Paulo city is the biggest city in Brazil and one of the biggest cities in the world. This region is the largest pole of national wealth. The Gross Domestic Product (GDP) corresponds to about 57\% of the total of the state of São Paulo. The cities that belong to metropolitan region of São Paulo are Arujá, Barueri, BiritibaMirim, Caieiras, Cajamar, Carapicuíba, Cotia, Diadema, Embu das Artes, EmbuGuaçu, Ferraz de Vasconcelos, Francisco Morato, Franco da Rocha, Guararema, Guarulhos, Itapevi, Itapecerica da Serra, Itaquaquecetuba, Jandira, Juquitiba, Mairiporã, Mauá, Mogi das Cruzes, Osasco, Pirapora do Bom Jesus, Poá, Ribeirão Pires, Rio Grande da Serra, Salesopolis, Santa Isabel, Santana de Parnaíba, Santo André, São Bernardo do Campo, São Caetano do Sul, São Lourenço da Serra, São Paulo, Suzano, Taboão da Serra e Vargem Grande Paulista.

A study demonstrated the importance of the green belt of Sao Paulo to preserve the environment, watershed protection areas, and water production. It was concluded, however, that it is difficult in adopting laws on the environment, low management capacity of producers, and obstacles in obtaining financing (QUEIROZ, 2013).

One of the reasons that prompted the declaration of the green belt of São Paulo as a biosphere reserve, it is due to the fact it surrounds one of the planet's largest cities that concentrates $10 \%$ of the Brazilian population, with very low rates of green area per inhabitant. The green belt brings a quality of life to the metropolis of Sao Paulo, supplying water and a variety of food. Rivers cut through the urban area, and this region is a habitat of great biodiversity of species, protects the soil from heavy rainfall, and ensures food safety of cities of the metropolitan area (INSTITUTO FLORESTAL, 2013).

The vegetables that are produced in the east region of the green belt, not only in Mogi das Cruzes but also in cities as Suzano, Biritiba-Mirim, and Salesópolis, occurs through a direct transaction with the small local retail or selling the central supermarkets supply chains. In case of sale to supermarket chains, the producer is responsible for the cost of shipping and other fees required by the company, however, it has a regular demand (SATO et al., 2006). 
INDEPENDENT JOURNAL OF MANAGEMENT \& PRODUCTION (IJM\&P)

http://www.ijmp.jor.br

v. 10, n. 2, March - April 2019

ISSN: 2236-269X

DOI: 10.14807/ijmp.v10i2.861

\section{RESEARCH METHODOLOGY}

As described in the introduction, the purpose of the study is to generate an overview of the Local Food Production. We adopted a case-study approach to allow a deeper insight into the features of LFP. A case study as a research strategy often emerges as a reasonable option for students and other new researchers who are seeking to undertake a minor scale research project based on their workplace or the comparison of a limited number of organizations.

Case studies are widely accepted because they may offer insights that might not be achieved with other approaches. Finally, case studies have often been seen as a useful tool for the preliminary, exploratory stage of a research project, as a basis for the development of the framework and the methods that are required for surveys and investigations (ROWLEY, 2002).

To investigate LFP, Mogi das Cruzes city was chosen for two purposes: for its significance in São Paulo urban area where the city is in charge to produce and to distribute the main portion of vegetables and also, due to the engagement of Secretary of Agriculture of the city with LFP and its aim to share the data to develop studies that can contribute to improving the delivery of produced food in the city.

This study was conducted through interviews with the team of the Secretary of Agriculture and professionals of this division. To identify general aspects of the food production in Mogi das Cruzes, they were asked to turn information available about the role of the government of the city in managing and supporting the local food production. In addition, they were asked to demonstrate studies, researchers and developed statistics by the local government in the past years. A documental research was also conducted including data such as food production, sales, employment, and the range of performed activities by the local government.

\section{RESULTS AND DISCUSSION}

Sao Paulo is one of the largest cities in the world. The estimated population is $12,106,920$ people, and the human development index is 0.805 (IBGE, 2017). Different foods types consumed in Sao Paulo are produced in the green belt of the city. The most influential city of the green belt is Mogi das Cruzes. The city is far 60 km from São Paulo city. Figure 1 shows the location of Mogi das Cruzes in the metropolitan region of Sao Paulo. 


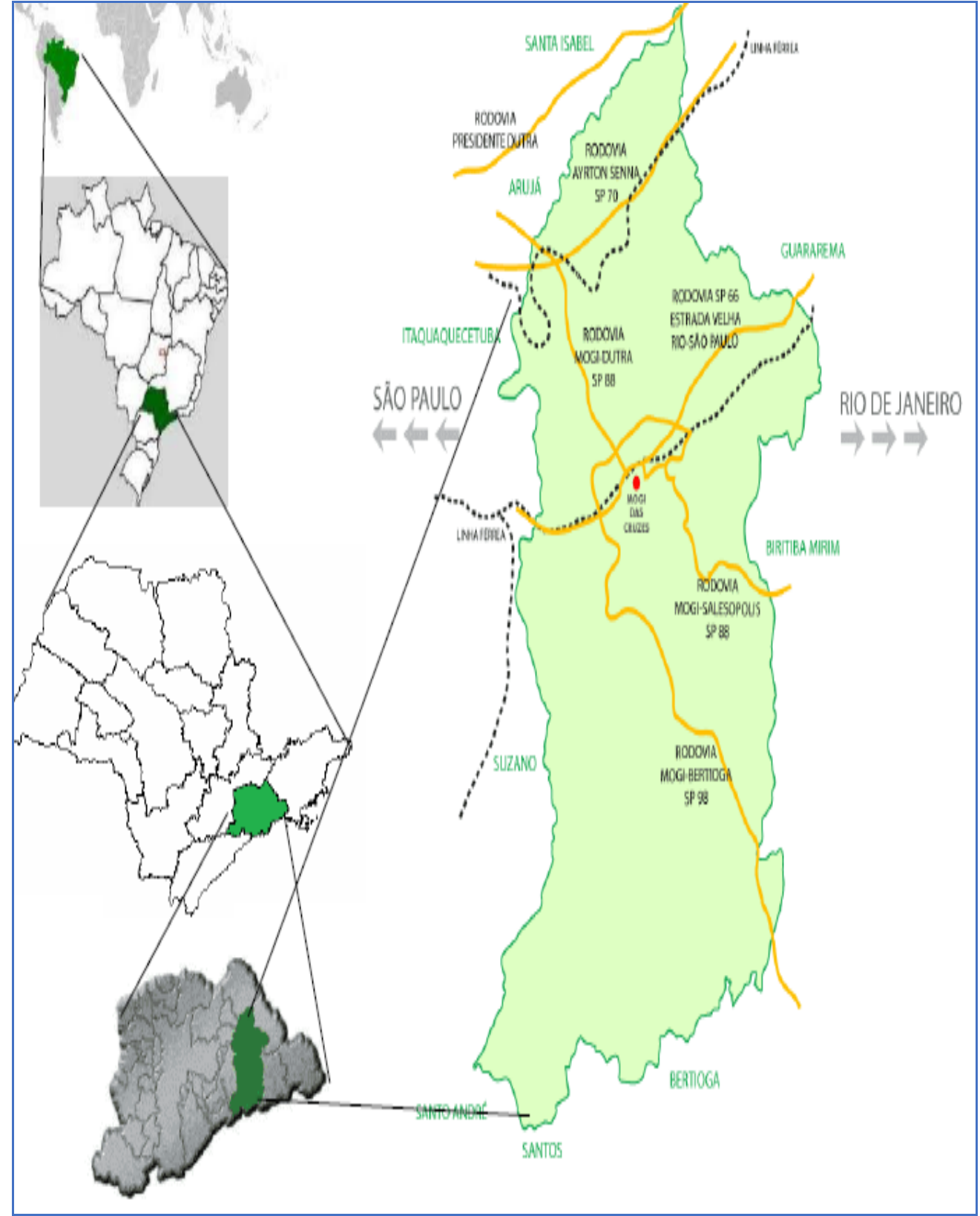

Figure 1: Location of Mogi das Cruzes city

The city of Mogi das Cruzes produces a wide range and different types of food such as fruits, vegetables, mushrooms, quail and ostrich eggs, rabbit meat and goat meat. The flowers production is considered a substantial activity in the city as well. Figure 2 provides the main products of the city for territory. 


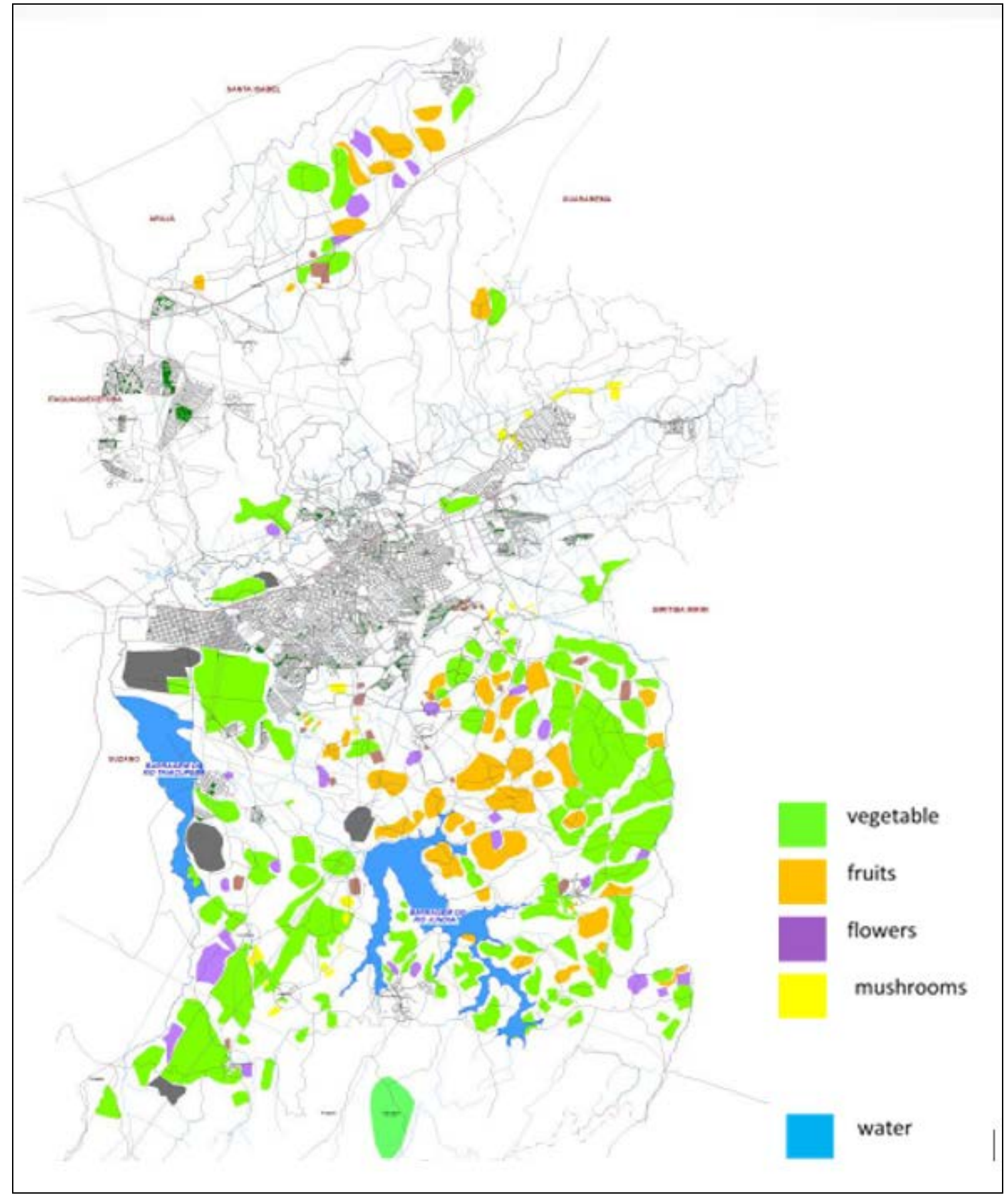

Figure 2: Areas of food production (Authors, 2018)

The monitoring and supporting of the local food production by the local government is a duty of the Secretary of Agriculture. It was founded in 2012, with the investment of BRL 974,000 . The team is composed of 15 professionals that perform a wide of public activities, as can be seen in Figure 3 . 


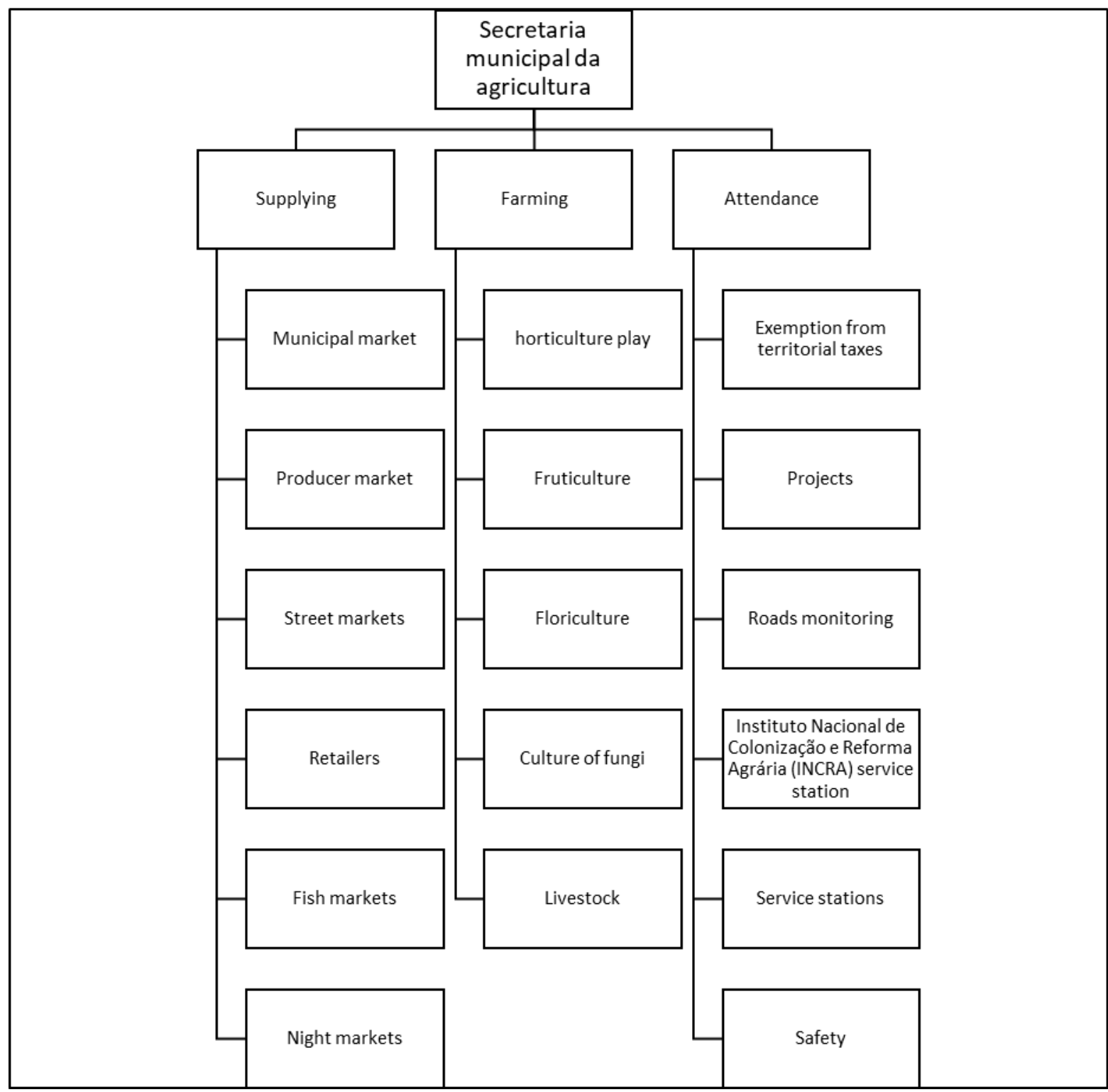

Figure 3: Activities of Secretary of Agriculture (authors, 2018)

In Figure 3 there are three subsectors that perform a wide range of activities. The first subsector (Supplying) takes care of the sales channels supported or managed by the government. There is two main sales point maintained by the Mogi das Cruzes public administration.

The local government supports the Municipal market and the Producer market where food producers sell their goods, paying a rent for the government. The local government manages the street markets, retailers, fish markets and night markets. The local producers have a license to sell the food production paying fees for the government of the city. 
INDEPENDENT JOURNAL OF MANAGEMENT \& PRODUCTION (IJM\&P)

http://www.ijmp.jor.br

v. 10, n. 2, March - April 2019

ISSN: 2236-269X

DOI: 10.14807/ijmp.v10i2.861

The municipal market is located in a rich area of the city. Its daily activities occur in a building of 2,000 square meters. The building has 113 stores that generate approximately 1,000 jobs, considering the direct and the not direct employees. The flow of people is around 3,500 per day. The annual sales are approximately BRL 60,000,000.00.

The producer market is established in an area where local producers can sell products in trailers, shops, and stands, just on Sundays. This business generates around 2,000 employees and the sales are approximately BRL 100,000,000.00 per year. Other minor markets and retailers generate about 1,200 employees and their sales are approximately BRL 40,000,000.00 per year.

Table 1: Supplying of local food (Source: authors, 2018)

\begin{tabular}{cccc}
\hline Segment & Selling locals & Employees & Anual Sales (BRL) \\
\hline Municipal market & 113 & 478 & $60,000,000.00$ \\
Producer market & 232 & 928 & $100,000,000.00$ \\
Street markets and retailers & 460 & 1185 & $40,000,000.00$ \\
Total & 805 & 2591 & $200,000,000.00$ \\
\hline
\end{tabular}

The second subsector is farming. The main objective of this subsector is supporting local producers and stimulating de food production. Moreover, intents to simplify the technical support to the local producers. The subsector is divided into these following categories:

- Horticulture play: lettuce and similar vegetables, parsley, chive and similar vegetables, bulbs and tubers as potato, sweet potato, carrot, turnip, cassava, garlic, onion, beetroot, cucumber

- Fruits: Khaki (rama forte, giombo, and fuyu types), medlar (fukuhara and mizuho types), atemoya (thompson and generic types), lemon, grape, banana, nectarine, avocado, pear, lychee, passion fruit, peach, tangerine, guava and plum

- Floriculture: flower in vases, cut flowers, ornamental plants

- The culture of fungi: edible mushrooms (champignon, shitake, white shimeji, black shimeji, pleurotus, portobello, mushroom of the sun, eryngui, nameko, and enoki

- Livestock: cattle for meat production, cattle for milk production, beekeeping, aviculture, posture poultry, goats, sheep, quail culture and fish farmingMogi das Cruzes has approximately 1.8 million animal calves. It is considered the 
INDEPENDENT JOURNAL OF MANAGEMENT \& PRODUCTION (IJM\&P)

http://www.ijmp.jor.br

v. 10, n. 2, March - April 2019

ISSN: 2236-269X

DOI: 10.14807/ijmp.v10i2.861

largest producer of orchids and hydrangeas of Brazil and it concentrates $60 \%$ of producers of mushrooms of the country. Table 2 shows data about production and sales.

Table 2: Farming production and sales (Source: authors, 2018)

\begin{tabular}{cccr}
\hline Segment & Production & Unit & Sales per year \\
\hline Horticulture play & 560 & 1000 tons & BRL 450,000,000.00 \\
Fruits & 31 & 1000 tons & BRL 60,000,000.00 \\
Flowers & 12 & millions of vases & BRL 100,000,000.00 \\
Fungi & 4,7 & 1000 tons & BRL 22,000,000.00 \\
Livestock & 1,8 & millions of animals & BRL $90,000,000.00$ \\
& & & BRL 722,000,000.00 \\
\hline
\end{tabular}

Attendance is the third subsector. Improving unpaved roads and exemption of taxes have been achieved by this subsector.

The unpaved roads are severely damaged by the traffic mainly in rainy periods. Local producers consider it is necessary a continuous improvement to decrease the food losses through the transport. During the current year, the local government or commercial partners improved $76 \mathrm{~km}$ of roads. The expenses were BRL 3,618,000.00.

The Exemption Program of Property Tax Territorial Urban, collected as a Rural Territorial Tax, guaranteed by municipal law, benefits the agricultural activity in areas considered as urban zones. The requests amount of the benefit is shown in Figure 4.

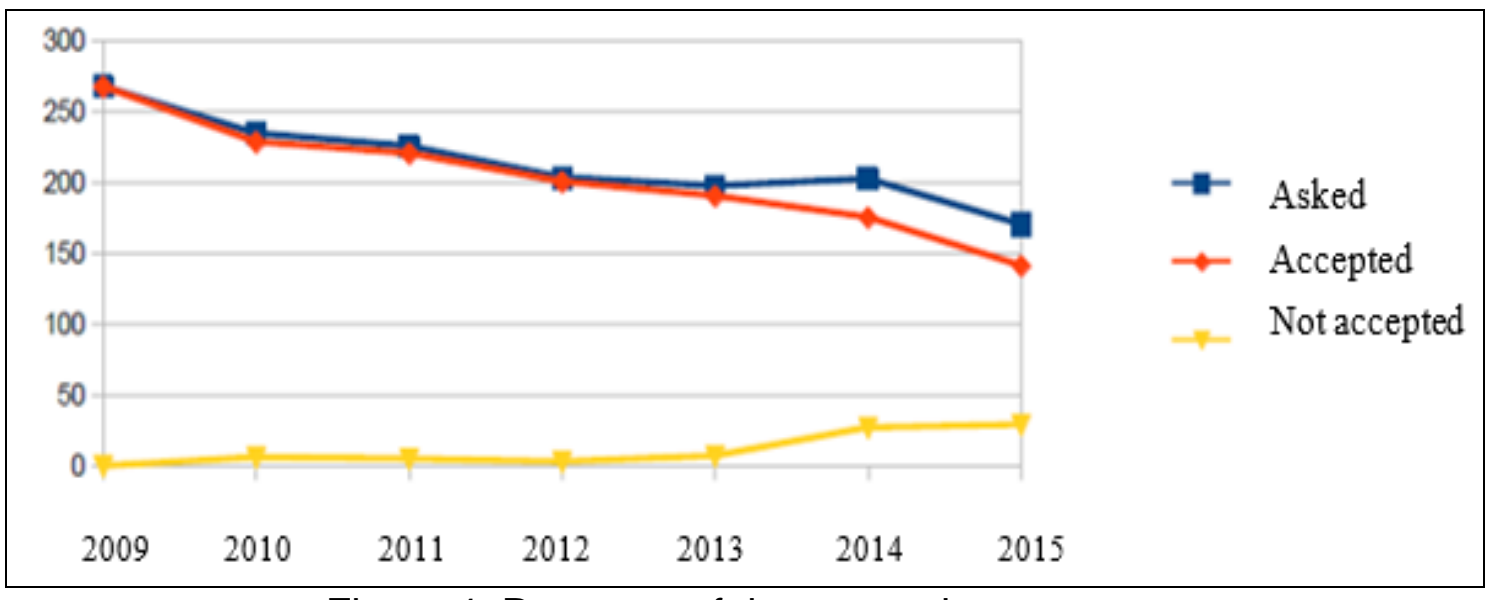

Figure 4: Requests of the exemption program

A range of other activities performed by the attendance subsector as listed below: 
- Instituto Nacional de Colonização e Reforma Agrária (INCRA) station, where the food producers can obtain licenses need for their activities (about 180 attendances by year)

- Rural safety meetings - food producers can present their safety proposals to the local police

- Public lights - lamps are installed in critical places in the rural zone, like schools, bus stations, and street crossroads

- Proposal and monitoring of projects as:

- PNAE - Programa Nacional de Alimentação Escolar (74.900 kg of vegetables purchased by local producers in 2016)

- PAA - Purchasing of the food program

- Crop launching (support for producers to calculate and sales prospecting)

- Including local food in the school's children meals, like mushrooms, vegetables, and fruits

- CAR - Cadastro Ambiental Rural - a partnership with The Nature Conservancy.

- Rural producer market

- New partnerships for roads maintenance

- Mercado Municipal safety program (safety types of equipment)

- Supplying natural gas by pipeline instead of gas cylinders

\subsection{Future Projects of The Local Government}

During the interviews, it was possible to identify information about the planning of local government of Mogi das Cruzes city for the next years. There is a program called Mogi 2040, where specialists, teachers, researchers, and government members work for finding new possibilities of supporting the local food producers. The main actions planned for the next 30 years are creating a Center of Educational Development, Scientific and Technological of Agribusinesses, creating a sector of Familiar agriculture business and production, marketing agribusiness program, agro production certification, farmer certification, higher efficiency of the 
INDEPENDENT JOURNAL OF MANAGEMENT \& PRODUCTION (IJM\&P)

http://www.ijmp.jor.br

v. 10, n. 2, March - April 2019

ISSN: 2236-269X

DOI: 10.14807/ijmp.v10i2.861

maintenance of roads process, agro-tourism program, familiar activities program and legal land property program.

The potential of the city of Mogi das Cruzes in consolidating itself as the main food producer city in the metropolitan region of Sao Paulo is based on different factors. The city has a privileged strategic location, close to the city of Sao Paulo, Guarulhos airport, the port of Santos and Dutra highway that links the two largest cities in Brazil, Sao Paulo and Rio de Janeiro.

The natural beauty of the region is also considered as a differential factor because it can attract tourists and help in attracting Government and private investments. The biggest challenges for the city of Mogi das Cruzes for keeping your role in food production in the coming years are the lack of training and qualification of the workforce, the lack of professionals, the preparation of the infrastructure, the family succession of properties and water scarcity.

\section{CONCLUSIONS AND OUTLOOK}

According to the presented literature review, Mogi das Cruzes is considered as the main town in the region of Sao Paulo's green belt, and it has the largest center of production of vegetables, fruits and flowers of Brazil, with a relevant share of the national market of mushrooms, persimmon, loquats, vegetables, and flowers.

In this study, the main purpose was to explore information of many aspects about local food production using as a case study the city of Mogi das Cruzes, considered as the most important city of the green belt of Sao Paulo, due to its wide range of food types raised in an area that is near of the biggest and the most important metropolitan area of Brazil.

It was asked how the local government supports and manage the local food production, how the local government monitors the activities of local production and how the local food is sold nearby with the support of the local government. The findings of this study suggest that the local government performs technical and legal actions and there is a concerning in supporting the local food producers, keep on this economic activity in a good level of efficiency and diversity.

The team that is in charge in the Secretariat of Agriculture accomplishes an assortment of actions, taking care of supplying and local sales issues, farming 
INDEPENDENT JOURNAL OF MANAGEMENT \& PRODUCTION (IJM\&P)

http://www.ijmp.jor.br

v. 10, n. 2, March - April 2019

ISSN: 2236-269X

DOI: 10.14807/ijmp.v10i2.861

requests. They keep a department for attending and helping food producers in a wide of subjects as taxes, roads maintenance, and licenses.

The city of Mogi das Cruzes says that there is no sufficient official data to support the strategic management of the Secretariat of Agriculture. Surveys are expensive and slow to be performed. Data collection from the producers, landowners, and occupiers of settlements, which are often poor people with low educational qualifications, are obtained with a lot of resistance and distrust, which turn the researches very complex. In addition, failures of launched programs by previous local governments keep the producers away and cause unknown and underutilization of the departments services.

The present study should prove to be particularly valuable to raise more ideas about on how the food production is supported in Mogi das Cruzes city and why this region is so important for the food supplying for the biggest metropolitan area of Brazil. New researches that allow bringing more knowledge about the provided services by the City Council and the problems faced by local food producers, especially on land grown by family farmers, are vital to reducing the stresses and difficulties of communication.

The local government can help local family producers with training programs. The Secretariat of Agriculture has in its staff, specialized technicians whom can tutor producers on legal issues, productivity, quality, logistical operations including inbound and outbound. Training can improve the dialogue between local authorities and producers to a close, reducing eventual underutilization of the offered services by the local government.

The scope of this study was limited to the information available in the prefecture of the Mogi das Cruzes. It was stated by the team of the local government that there are no official data about the local food production of Mogi das Cruzes enough to support all the strategic planning, and to generate these data through specialized companies of research is expensive.

Further research should be undertaken to investigate the results of the investments and actions from a producer point of view and the local community in general. The small quantity of data did not allow to know what are the difficulties that 
INDEPENDENT JOURNAL OF MANAGEMENT \& PRODUCTION (IJM\&P)

http://www.ijmp.jor.br

v. 10, n. 2, March - April 2019

ISSN: 2236-269X

DOI: 10.14807/ijmp.v10i2.861

producers have in logistics, labor, funding, purchasing of fertilizer, seeds and equipment and the various factors of production.

\section{REFERENCES}

AGGESTAM, V.; FLEIß, E.; POSCH, A. (2017) Scaling-up short food supply chains? A survey study on the drivers behind the intention of food producers. J. Rural Stud., v. 51 , p. 64-72.

BARBIZAN, T. (2011) Integrating Urban and Peri-Urban Agriculture into Public Policies to Improve Urban Growth: São Paulo as a Case Study. Dissertation (Master of Science). Berlin: Technische Universität Berlin

BOSONA, T. G.; GEBRESENBET, G. (2011) Cluster building and logistics network integration of local food supply chain, Biosystems Engineering, v. 108, n. 4, p. 293302.

DA SILVA, M. P.; BONINI, L. M. M.; CANDIDA, V. B. (2015) A imigração japonesa e o desenvolvimento regional: histórias e memórias do Alto Tietê. In: Seminário Internacional sobre Desenvolvimento Regional, 7, Santa Cruz do Sul,

Proceedings... Santa Cruz do Sul : 2015.

FAO (2013) Food Wastage Footprint. Impact on Natural Resources.

Available:http://www.fao.org/documents/card/en/c/000d4a32-7304-5785-a2f1f64c6de8e7a2. Access 6th August, 2016.

IBGE (2017) Brasil em Síntese: São Paulo. Available:

https://cidades.ibge.gov.br/brasil/sp/sao-paulo/panorama. Acess: 9th September, 2017.

INSTITUTO FLORESTAL (2013) O cinturão verde. Available:

http://iflorestal.sp.gov.br/o-instituto/rbcv/o-cinturao-verde/. Access 21th July, 2017.

JAROSZ, L. (2011) Nourishing women: toward a feminist political ecology of community supported agriculture in the United States. Gend. Place Cult. 18, 307326.

JONES, P.; COMFORT, D.; HILLIER, D. (2004) A case study of local food and its routes to market in the UK. Br. Food J., v. 106, p. 328-335.

MIGLIORE, G.; SCHIFANI, G.; CEMBALO, L. (2015) Opening the black box of food quality in the short supply chain: Effects of conventions of quality on consumer choice. Food Qual. Prefer., v. 39, p. 141-146.

MIGLIORE, G.; SCHIFANI, G.; GUCCIONE, G. D.; CEMBALO, L. (2014) Food Community Networks as Leverage for Social Embeddedness. J. Agric. Environ. Ethics, v. 27, p. 549-567.

MOUNT, P. (2017) Growing local food: scale and local food systems governance. Agriculture and Human Values, v. 29, n. 1, p. 107-121.

NIE, C.; ZEPEDA, L. (2011) Lifestyle segmentation of US food shoppers to examine organic and local food consumption. Appetite, v. 57, p. 28-37.

QUEIROZ, G. C. M. (2013) Fortalecimento e fragmentação do cinturão verde do Alto Tietê: perspectivas sobre a atividade agrícola da região Available: http://repositorio.uscs.edu.br/handle/123456789/307. Access 20th June, 2017. 
ROWLEY, J. (2002). Using case studies in research. Manag. Res. News, v. 25, p. $16-27$.

SANTOS, V. N.; BELLO, E. M. (2014) Aspectos gerais da cultura alimentar do município de Mogi das Cruzes - SP. Rev. Científica Linkania Master, v. 1.

SATO, G. S.; MARTINS, S. S.; CARVALHO, Y. M. C.; MILANI, A. A.; CUNHA, R. P. (2006) Fluxo de comercialização de hortaliças produzidas na região Alto Cabeceiras do Tietê. In: Congresso Sociedade Brasileira de Economia, Administracao e Sociologia Rural, 44, Fortaleza, Proceedings... Fortaleza: SOBER: 2006

USDA ERS (2017) Trends in U.S. Local and Regional Food Systems: A Report to Congress. Available: https://www.ers.usda.gov/publications/pubdetails/?pubid=42807. Access 21th June, 2017. 